\title{
ANALISIS KEGAGALAN IMPELLER PENYEBAB KERUSAKAN POMPA AIR KAPAL LAUT
}

\section{IMPELLER FAILURE ANALYSIS CAUSES OF SENTRIFUGAL PUMP DAMAGE FROM SHIP UNIT}

\author{
Eka Febriyanti, Sutarjo, Khairul Anwar \\ Perekayasa Pada Balai Besar Teknologi Kekuatan Struktur, BPPT \\ Kawasan PUSPIPTEK, Serpong, Tangerang 15314 \\ Tel. (021)-7560539; Fax. (021)-7560538 \\ e-mail : eka.febriyanti@bppt.go.id, sutarjodurrahman@yahoo.com, khairul.anwar@yahoo.com
}

\begin{abstract}
Abstrak
Impeller merupakan bagian dari pompa sentrifugal yang digunakan untuk kapal laut dan telah mengalami korosi seragam secara signifikan setelah satu tahun pengoperasian. Impeller terbuat dari ASTM B198-13A, grade C87400 yang merupakan jenis silicon brass. Hasil pemeriksaan visual menunjukkan bahwa seluruh permukaan kecuali pada bagian yang dilindungi oleh cat mengalami proses korosi di seluruh permukaan. Sedangkan pemeriksaan SEM menunjukkan adanya selective etching fasa-fasa tertentu. Hal pemeriksaan tersebut juga dikonfirmasi dengan pemeriksaan metalografi dimana menunjukkan adanya leaching dari fasa yang kaya akan unsur Zinc mendekati zona terekspos. Oleh karena itu, mekanime korosi yang terjadi mengarah pada dezincfication. Analisis komposisi kimia dari impeller menunjukkan bahwa material impeller yang diperiksa merupakan jenis silicon brass yang tidak tahan terhadap serangan klorida dibandingkan leaded red brass. Dalam rules klas/ marine klas umumnya menggunakan material leaded gunmetal bronze yang mengacu pada spesifikasi ASTM B584-836 atau SAE 40 atau UNS C83600 atau lebih dikenal dengan leaded red brass. Leaded red brass mempunyai karakteristik seperti machinability yang sangat baik, ketahanan aus yang sangat baik pada pelumasan normal, serta ketahanan terhadap korosi, fatik, dan impak yang baik. Selain itu, material ini juga memiliki kualitas permukaan yang sangat baik, konduktivitas yang baik, dan sekaligus tahan terhadap air laut. Oleh karena itu, material leaded red brass sering diaplikasikan pada produk marine ${ }^{1-3]}$.
\end{abstract}

Kata Kunci : Impeller, pompa, kapal laut, korosi, dezinfication

\begin{abstract}
An impeller that was part of a sentrifugal pump used in potable ship was found to have experienced significant corrosion after only one year of service. The impeller was made from ASTM B198-13A, grade C87400 which is a silicon brass. The visual examination showed extensive metal loss on all surfaces. SEM examination showed selective etching of certain phases. This was confirmed with the metallographic examination which showed leaching of the zinc-rich phases close to the exposed surface. The corrosion mechanism was therefore found to be dezincification. A chemical analysis of the impeller material revealed that it was silicon brass and is not as resistant to chloride attack as leaded red brass. In rules klas/marine klas impeller generally uses leaded gunmetal bronze material refers to ASTM B584-836 spesification also called SAE 40 or UNS C93600. This grade is also known "leaded red brass". Leaded red brass offers characteristic such as excellent machinability, excellent wear resistant at normal lubrication, with good resistance to corrosion, fatigue, and impact. Moreover, this material has also anti frictional and excellent quality, good conductivity, and good corrosion resistance to
\end{abstract}


seawater. Therefore, leaded red brass material is often applied to marine products $^{1-3)}$.

Keywords: Impeller, pump, ship, corrosion, dezinfication

Diterima (received) : 13 Juni 2017, Direvisi (reviewed) : 8 Juli 2017, Disetujui (accepted) : 29 Juli 2017

\section{PENDAHULUAN}

Pompa sentrifugal salah satu jenis Variable Displacement Pump. Prinsip kerja dari Variable Displacement Pump adalah volume air per menit yang dilewatkan tidak sama dengan volume air yang dihisap setiap menitnya. Pompa ini memiliki prinsip dimana perpindahan zat aliran didasarkan atas adanya gaya sentrifuga| ${ }^{4}$.

Untuk dapat bekerja, pompa membutuhkan daya dari mesin penggerak pompa, dimana di dalam pompa fluida terjadi percepatan sedemikian rupa sehingga fluida tersebut mempunyai kecepatan mengalir keluar dari sudu-sudu. Kecepatan keluarnya fluida ini akan berkurang akibat perubahan kenaikan fluida yang dialirkan melalui sudusudu ke pipa outlet. Besarnya tekanan yang timbul tergantung pada besarnya kecepatan fluida ${ }^{5}$.

Pompa ini terdiri dari impeller yang dipasang pada sebuah poros berputar dalam rumah pompa (casing) atau rumah keong (volute casing) serta memiliki saluran masuk (suction) dan keluaran (discharge) fluida. Impeller yang berputar menimbulkan tekanan dalam air. Pada tengah impeller, air keluar melalui sudu-sudu dengan kecepatan yang diakibatkan adanya gaya sentrifugal sehingga arah aliran yang keluar dari impeller tegak lurus terhadap aliran yang menuju ke pusat sudu impeller6) seperti yang terlihat pada Gambar 1.

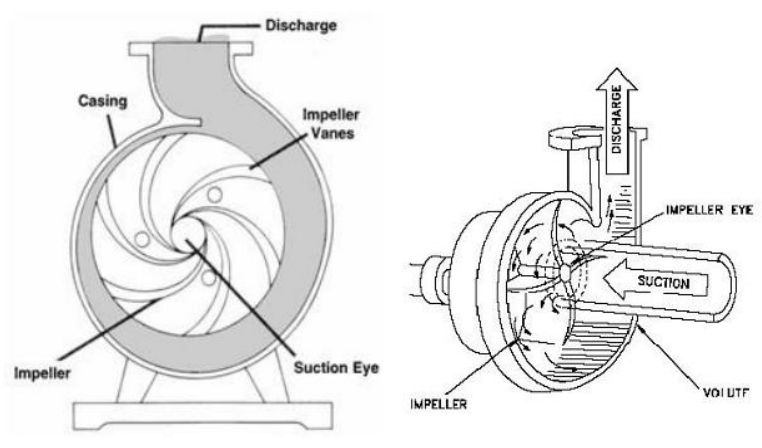

Gambar 1.

Bagian-bagian pompa sentrifuga| ${ }^{5}$ )

Impeller pada pompa merupakan bagian yang mengubah energi mekanik (energi pada sudu-sudu impeller) diteruskan kepada daya pompa dan akibat adanya efisiensi karena perubahan arah aliran pada sudu-sudu impeller).

\section{Kronologis}

Impeller pompa sentrifugal dilaporkan mengalami kerusakan setelah 1 tahun pengoperasian. Pompa yang diteliti merupakan pompa ke-satu, dan merupakan pompa yang paling banyak digunakan dari ketiga sistem pompa yang didesain untuk menggerakkan kapal laut. Masalah pada pompa ditemukan ketika terdengar gangguan suara berlebih yang keluar dari pompa. Gambaran desain menyebutkan bahwa impeller terbuat dari material B19813A Grade C87400 yaitu merupakan tipe (silicon brass) (82 Cu-0,5 Pb-14 Zn-3,5 Si) ${ }^{7}$.

Grade C87400 merupakan paduan kuningan hasil coran dan yang mempunyai tegangan tinggi (high strength) dan merupakan solid solution strengthened. Material silicon brass mengandung $\mathrm{Zn} \leq 20 \%$ dan $\mathrm{Si} \leq 6 \%$. Selain itu material cast silicon brass memiliki ketahanan korosi yang sangat baik terutama pada lingkungan aqueous dan atmosferik. Namun, ketahanan korosi silicon brass pada lingkungan air laut (lingkungan klorida) lebih rendah dibandingkan leaded red brass. Konduktivitas paduan kuningan dari silicon brass lebih rendah dibandingkan paduan tembaga murni 2-3).

Dalam rules klas/marine klas biasanya menggunakan material leaded gunmetal bronze yang mengacu pada spesifikasi ASTM B584-836 atau SAE 40 atau UNS C83600 atau lebih dikenal dengan leaded red brass. Leaded red brass mempunyai karakteristik seperti machinability yang sangat baik, ketahanan aus yang sangat baik pada pelumasan normal, serta ketahanan terhdap korosi, fatik, dan impak yang baik. Selain itu, material leaded red brass juga memiliki kualitas permukaan yang sangat baik, konduktivitas yang baik, dan sekaligus tahan terhadap air laut. Oleh karena itu, material leaded red brass sering diaplikasikan pada produk marine ${ }^{1-3)}$. Pada lingkungan sea water yang diatur dalam rules klas/marine klas, paduan kuningan 
(paduan $\mathrm{Cu}-\mathrm{Zn}$ ) sering mengalami dezinfication. Dezinfication merupakan selective dissolution unsur $\mathrm{Zn}$ yang terjadi pada paduan kuningan (Cu-Zn) yang mempunyai kandungan $\mathrm{Zn}$ lebih dari $15 \%$ yang terekspos aerated water yang mengandung $\mathrm{CO}_{2}$ dan klorida yang tinggi. Dezinfication dapat diminimalisir dengan mengurangi agresivitas lingkungan (misalnya dengan oxygen removal atau dengan proteksi katodik, namun kedua metode tersebut tidak ekonomis. Biasanya menggunakan paduan yang kurang rentan terhadap dezinfication seperti red brass (15\% Zn) dan admiralty metal (70\% Cu, 29\% $\mathrm{Zn}, 1 \% \mathrm{Sn}$, dan $0,04 \%$ As). Bahkan untuk lingkungan yang sangat korosif dimana dezinfication muncul atau untuk bagianbagian kritis menggunakan cupronickel (70$90 \% \mathrm{Cu}, 30-10 \% \mathrm{Ni})^{[8-9]}$.

Lalu, impeller yang rusak diuji dan diperiksa di laboratorium supaya akar penyebab kerusakan dapat ditemukan. Hal ini dilakukan untuk mempercepat proses perbaikan dan mencegah terjadinya kerusakan serta kerugian yang sama di pengoperasian selanjutnya.

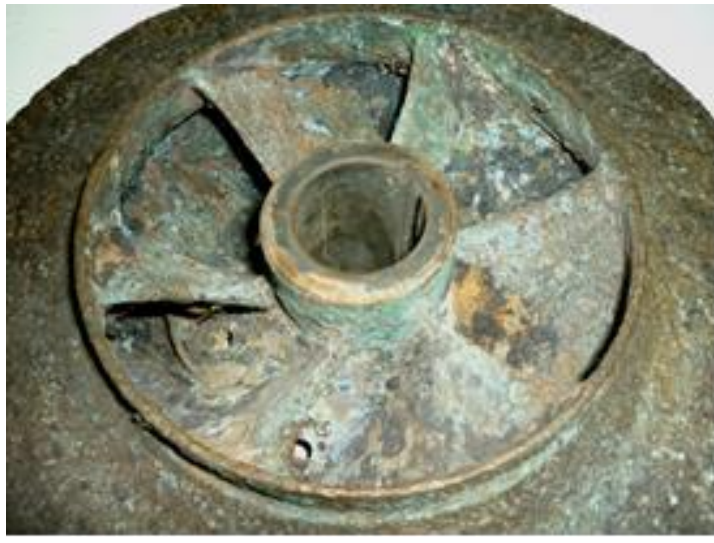

Gambar 2.

Impeller yang Mengalami Korosi Seragam di Permukaan

\section{BAHAN DAN METODE}

Metode penelitian terhadap impeller yang mengalami kerusakan perlu mengacu pada Rules Klas karena tergolong marine use yang digunakan dalam kapal.

Tahapan analisis kerusakan impeller menurut rules klas/ marine klas dari Biro Klasifikasi Indonesia (BKI) terdiri atas pemeriksaan visual yang bertujuan untuk mengidentifikasi awal kerusakan seperti retak, deformasi, efek kavitasi, dll. Selanjutnya dilakukan pemeriksaan non destructive untuk mendeteksi adanya retak. Selanjutnya dilakukan analisis mikroskopik untuk mengidentifikasi proses kerusakan ${ }^{10)}$.

Di bawah ini merupakan tahapan analisis kerusakan terhadap impeller kapal yang mengacu pada Rules Klas (BKI) seperti dapat dilihat pada Gambar 3:

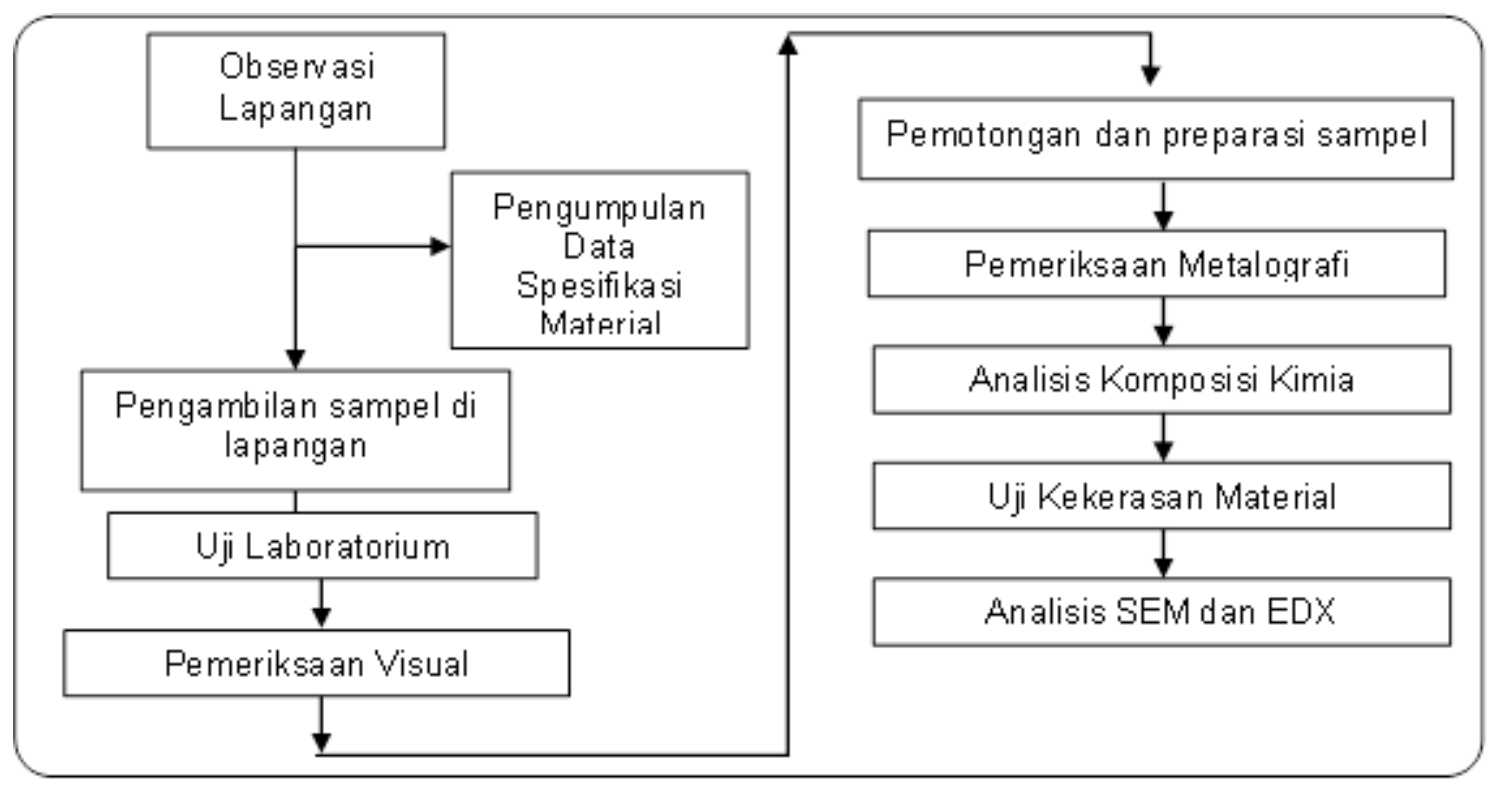

Gambar 3.

Diagram Alir Pemeriksaan dan Pengujian terhadap Impeller yang Mengalami Korosi Seragam 


\section{Pemeriksaan Visual}

Analisis visual dan pengamatan
menggunakan (perbesaran 40x) dilakukan secara detail pada impeller yang diterima di laboratorium. Hasil pemeriksaan menunjukkan bahwa impeller pompa mengalami serangan korosi seragam (uniform corrosion) di seluruh permukaan ${ }^{11)}$ seperti yang terlihat pada Gambar 4. Selain itu, permukaan sudu impeller pompa juga mengalami korosi pitting secara merata di bagian dalam maupun luar seperti yang terlihat pada Gambar 5.

Serangan korosi yang terjadi adalah serangan uniform corrosion dengan penampakan seperti busa (spongy) di daerah lainnya. Selain itu, daerah yang terserang korosi dan terkena pitting mengandung produk korosi berwarna "hijau" atau disebut "green corrosion residu"12).

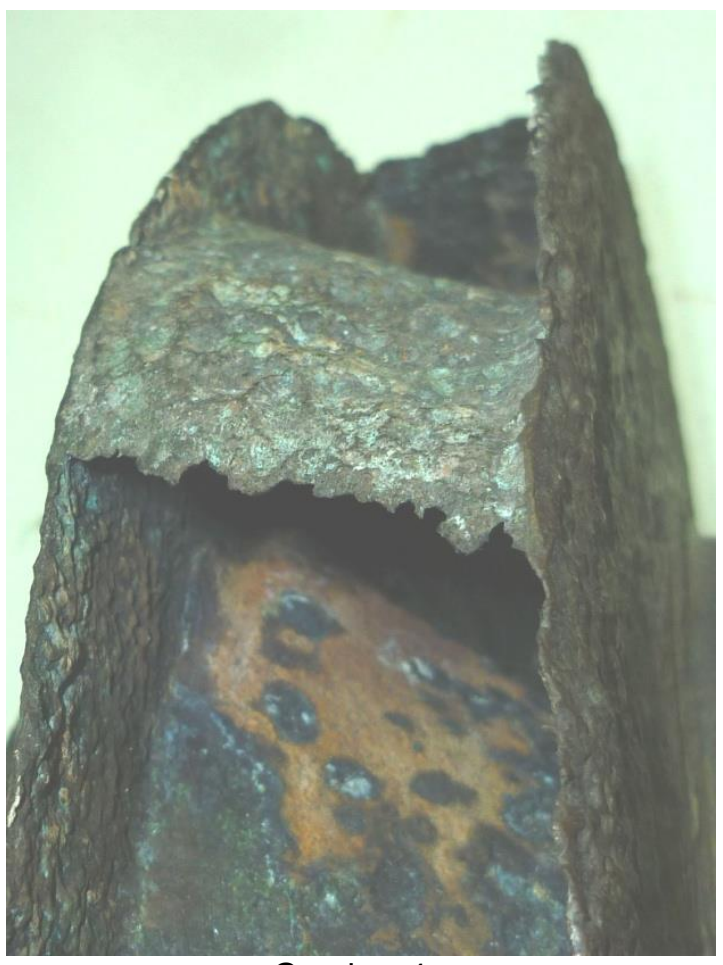

Gambar 4.

Pemeriksaan Impeller yang Mengalami Korosi Seragam pada Permukaan

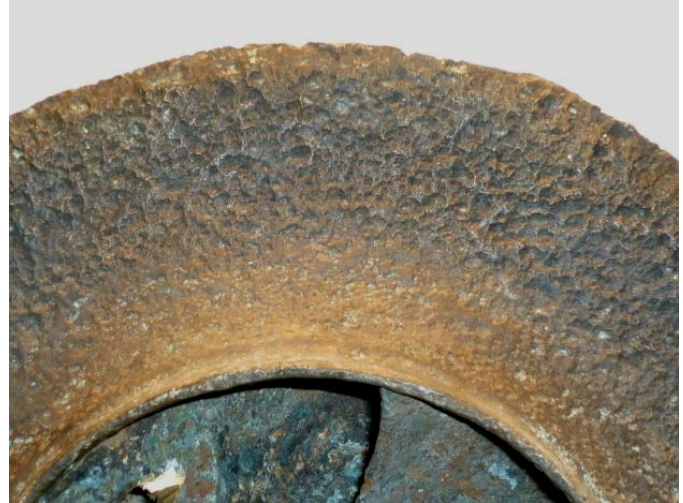

Gambar 5.

Permukaan Sudu Impeller Pompa

Mengalami Korosi Piting secara Merata di Bagian Luar maupun Dalam

\section{Pemeriksaan Metalografi}

Pemeriksaan metalogragfi dilakukan untuk mengetahui pengaruh serangan korosi terhadap struktur mikro impeller. Hasil pengamatan secara mikro menggunakan mikroskop optik dengan perbesaran 200x dan 500x yang dapat dilihat dar Gambar 6 sampai Gambar 9.

Pengambilan foto mikro etsa sampel metalografi terdiri atas 4 sampel yaitu sampel 1 dan 2 di daerah dinding sudu propeller, sampel 3 di lokasi sudu lining edge, dan sampel 4 di lokasi sudu trilling edge.

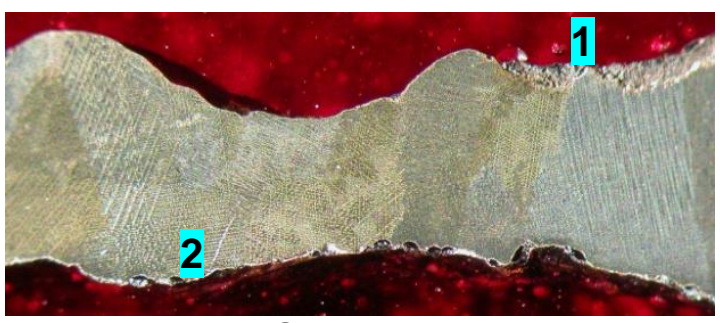

Gambar 6.

Sampel 1 (Dinding Sudu Pengarah)

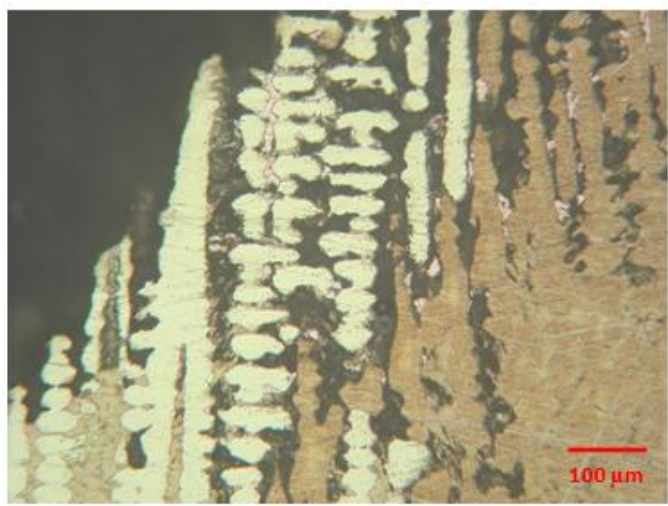

Gambar 7.

Struktur Mikro Sampel 1, Lokasi 1 pada Dinding Sudu Daerah Tepi Material Impeller $\mathrm{Zn}$-chill Cast berupa segregated- $\alpha$ dendrites dan Mengalami Serangan Korosi Melalui Batas Butir 


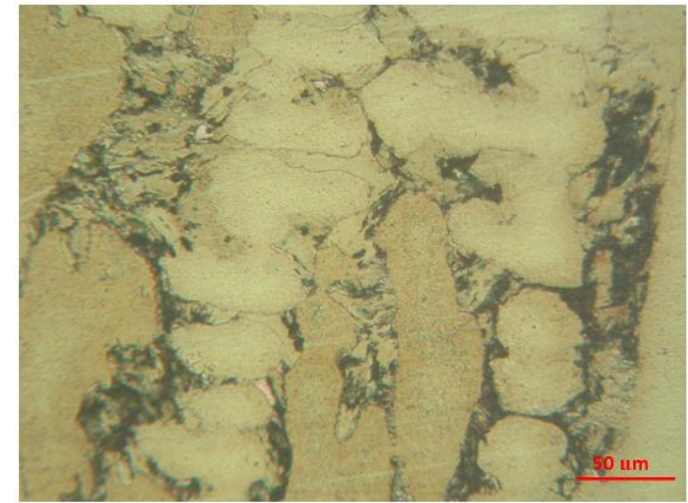

Gambar 14.

Struktur Mikro Sampel 3 bagian Liding edge Lokasi 2 pada daerah tepi

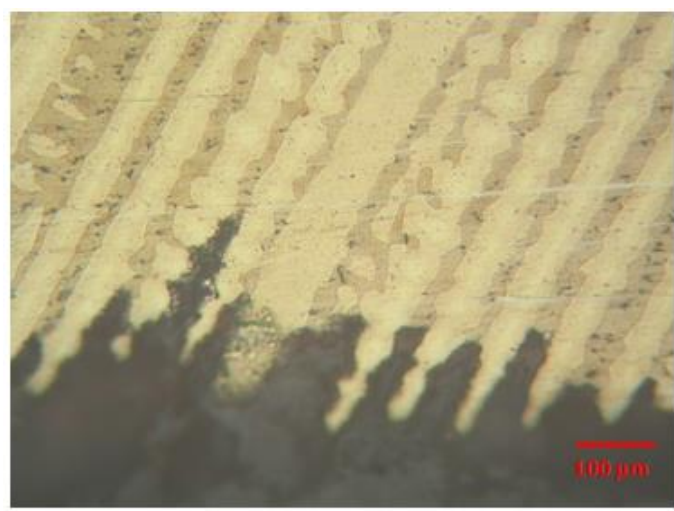

Gambar 15

Struktur Mikro Sampel 3 bagian Liding edge Lokasi 3 pada daerah tepi 4 berupa berupa segregated- $\alpha$ dendrites dan mengalami serangan korosi merata melalui batas butir

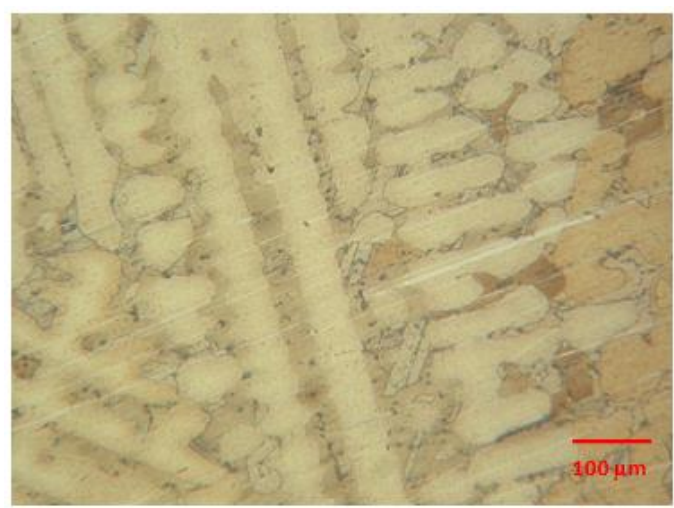

Gambar 16.

Struktur Mikro Sampel 3 bagian Liding edge Lokasi 4 pada daerah tepi berupa berupa segregated- $\alpha$ dendrites dan mengalami serangan korosi merata melalui batas butir

Untuk sampel 4 (sudu trilling edge) di lokasi 1, 2, dan 3 pada daerah tepi juga menunjukkan bahwa struktur mikro berupa segregated- $\alpha$ dendrites ${ }^{13)}$ dan mengalami serangan korosi pitting ${ }^{11)}$ dan merata melalui batas butir ${ }^{11)}$ seperti yang terlihat pada Gambar 17 s/d Gambar 20.

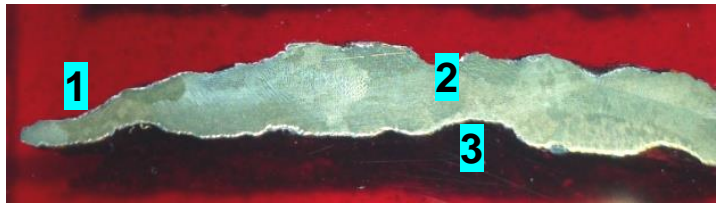

Gambar 17.

Sampel 4 (Sudu Trilling Edge)

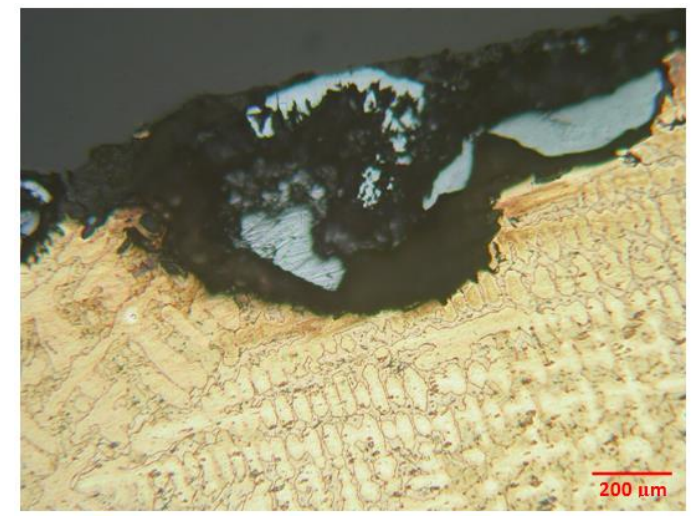

Gambar 18.

Struktur Mikro Sampel 4 bagian Trilling edge Lokasi 1 pada daerah tepi berupa segregated$a$ dendrites dan mengalami serangan korosi pitting dan merata melalui batas butir

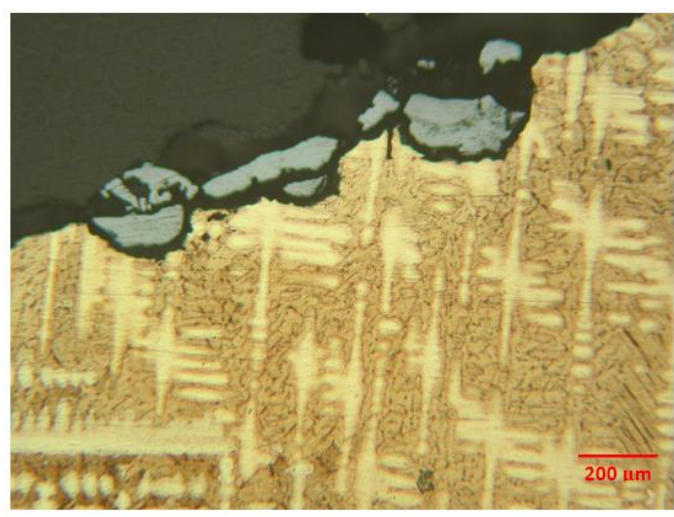

Gambar 19.

Struktur Mikro Sampel 4 bagian Trilling edge Lokasi 2 pada daerah tepi

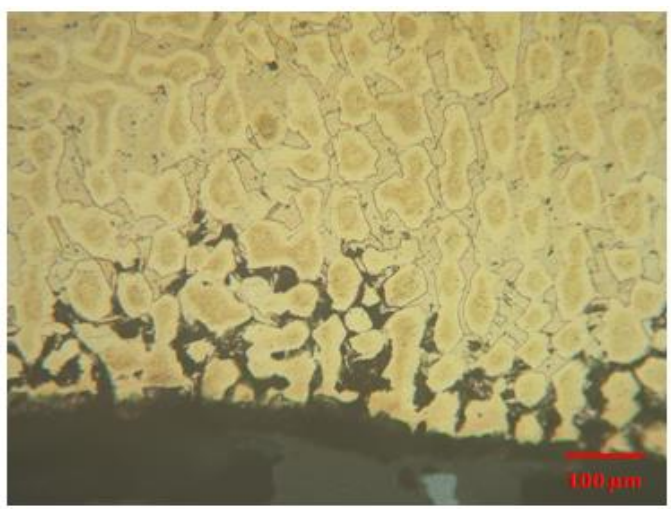

Gambar 20

Struktur Mikro Sampel 4 bagian Trilling edge Lokasi 3 pada daerah tepi 
Hasil pemeriksaan metalografi pada sampel diambil dari spongy area pada permukaan impeller. Permukaan sampel yang di-mounting, dipoles, dan dietsa dengan $\mathrm{K}_{2} \mathrm{Cr}_{2} \mathrm{O}_{7}+\mathrm{H}_{2} \mathrm{SO}_{4}$. Pemeriksaan metalografi menunjukkan bahwa permukaan lapisan pada kedalaman tertentu sangat berbeda dari hasil pengecoran. Pemeriksaan yang lebih detail pada permukaan lapisan ini seperti yang terlihat pada Gambar $6 \mathrm{~s} / \mathrm{d}$ Gambar 20. Namun, fasa zinc interdendritic mengalami selective etching ${ }^{15}$ sehingga mempengaruhi performa dari logam.

\section{Analisis Komposisi Kimia}

Sampel untuk analisis komposisi kimia diambil dari impeller pompa lalu diuji dengan optical emission spectrometer (OES). Hasil pengujian komposisi kimia material dari impeller dapat. Hasil uji menunjukkan bahwa material impeller yang diperiksa sesuai dengan standar material ASTM B198-13A (silicon brass) Grade C8740016) seperti yang terlihat pada Tabel 1.

Tabel 1.

Hasil Uji Komposisi Kimia Impeller

\begin{tabular}{|c|c|c|}
\hline $\begin{array}{l}\text { Unsur / } \\
\text { Elemen }\end{array}$ & Impeller & $\begin{array}{c}\text { Standar } \\
\text { ASTM B198- } \\
\text { 13A } \\
\text { Grade } 87400\end{array}$ \\
\hline $\mathrm{Fe}$ & 0,179 & \\
\hline $\mathrm{Si}$ & 3,43 & Max. 3,5 \\
\hline $\mathrm{Mn}$ & 0,0106 & \\
\hline $\mathrm{Cr}$ & $<0,001$ & \\
\hline $\mathrm{Ni}$ & 0,0727 & \\
\hline $\mathrm{Cu}$ & 80,4 & Max. 82 \\
\hline Al & $<0,0010$ & \\
\hline $\mathrm{Ti}$ & $<0,0010$ & \\
\hline $\mathrm{Zn}$ & 15,8 & Min. 14 \\
\hline $\mathrm{Ag}$ & 0,0249 & \\
\hline Sn & 0,014 & \\
\hline $\mathrm{Pb}$ & $<0,20$ & Max. 0,5 \\
\hline $\mathrm{Mg}$ & $<0,0005$ & \\
\hline Co & $<0,0020$ & \\
\hline $\mathrm{Cd}$ & $<0,0020$ & \\
\hline
\end{tabular}

\section{Pengujian Kekerasan}

Hasil uji kekerasan terhadap impeller dapat dilihat pada Tabel 2. Hasil uji menunjukkan bahwa untuk permukaan sampel 1, sampel 2, sampel 3, dan sampel 4 impeller memiliki nilai kekerasan masingmasing sekitar 124 - $146 \mathrm{HV}, 130-141 \mathrm{HV}$, 114-131 HV, dan 117-131 HV. Nilai kekerasan yang diperoleh pada keempat sampel sesuai dengan standar ASTM B19813A kecuali di beberapa titik pada sampel 1 dan Sampel 2 memiliki kekerasan standar ASTM B198-13A (80-137 HV) ${ }^{16)}$.

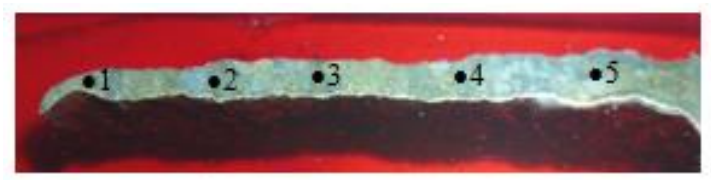

Gambar 21.

Sampel 1 Uji Kekerasan Impeller

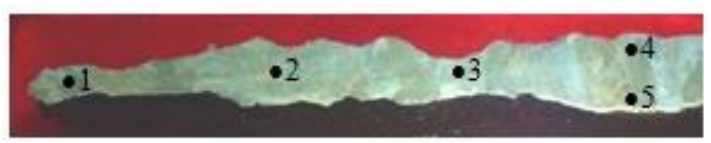

Gambar 22.

Sampel 2 Uji Kekerasan Impeller

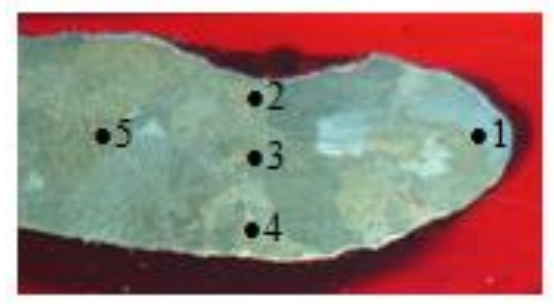

Gambar 23.

Sampel 3 Uji Kekerasan Impeller

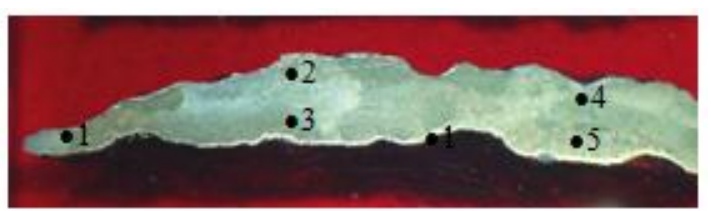

Gambar 24

Sampel 4 Uji Kekerasan Impeller 
Tabel 2.

Hasil Uji Kekerasan Impeller

\begin{tabular}{cc}
\multicolumn{2}{c}{ Hasil Uji Kekerasan Impeller } \\
\hline No. & $\begin{array}{c}\text { Nilai Kekerasan } \\
(\mathbf{H V})\end{array}$ \\
\hline & Sampel 1 \\
1 & 146 \\
2 & 141 \\
3 & 132 \\
4 & 133 \\
5 & 124 \\
Rata- & \\
rata & $\mathbf{1 3 5}$ \\
ASTM & \\
B 198- & $\mathbf{8 0 - 1 3 7}$ \\
13A &
\end{tabular}

Sampel 2

$$
1
$$$$
2
$$$$
3
$$

4

5

Ratarata

ASTM

B 198-

13A

\begin{tabular}{cc}
1 & Sampel 3 \\
2 & 131 \\
3 & 123 \\
4 & 114 \\
5 & 120 \\
Rata- & 127 \\
rata & 123 \\
ASTM & \\
B198- & \\
13A & \\
& \\
& \\
1 & Sampel 4 \\
2 & \\
3 & $\mathbf{1 1 7}$ \\
4 & \\
5 & \\
Rata- & \\
rata & \\
ASTM & \\
\hline
\end{tabular}

\section{B198-}

13A

Sumber Data: Hasil pengujian dengan menggunakan alat Frank Finotest

\section{Analisis SEM dan EDX}

Sampel untuk analisis SEM (Scanning Electron Microscope) diambil dari daerah yang terkorosi pada permukaan impeller pompa. Pemeriksaan SEM menunjukkan bahwa impeller pompa telah mengalami serangan korosi merata dan telah tertutup produk korosi. Hal ini menunjukkan bahwa mekanisme selective leaching terjadi pada silicon brass base metal. Selective leaching tampak dari bentuk pola dendritik dari pengecoran sperti yang terlihat pada Gambar 25 s/d Gambar 27 dalam skala mikroskopik.

Sedangkan sampel "green" corrosion residu dari daerah impeller yang terkorosi dilakukan pemeriksaan menggunakan analisis semi-kuantitatif EDS (Energy Dispersive Spectroscopy). Hasil analisis menunjukkan bahwa "green" corrosion residu mengandung unsur $\mathrm{Si}, \mathrm{Fe}, \mathrm{Cu}$, dan $\mathrm{Zn}$ masing-masing sebesar $0,55 \%$; $1,17 \%$; $52,56 \%$; dan $2,61 \%$; serta sejumlah unsur korosif yaitu ion $\mathrm{Cl}^{-}$sebesar $0,33 \%$ dan ion S $^{2-}$ sebesar $1,07 \%$. Hasil analisis EDS seperti yang terlihat pada Tabel 3 .
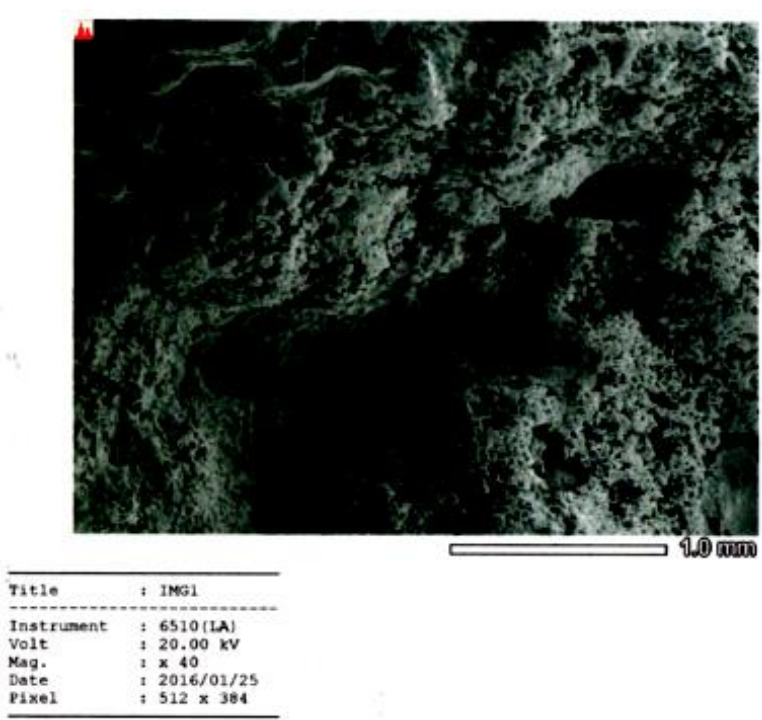

Gambar 25.

Hasil SEM dari Permukaan Impeller Pompa pada Posisi 1 

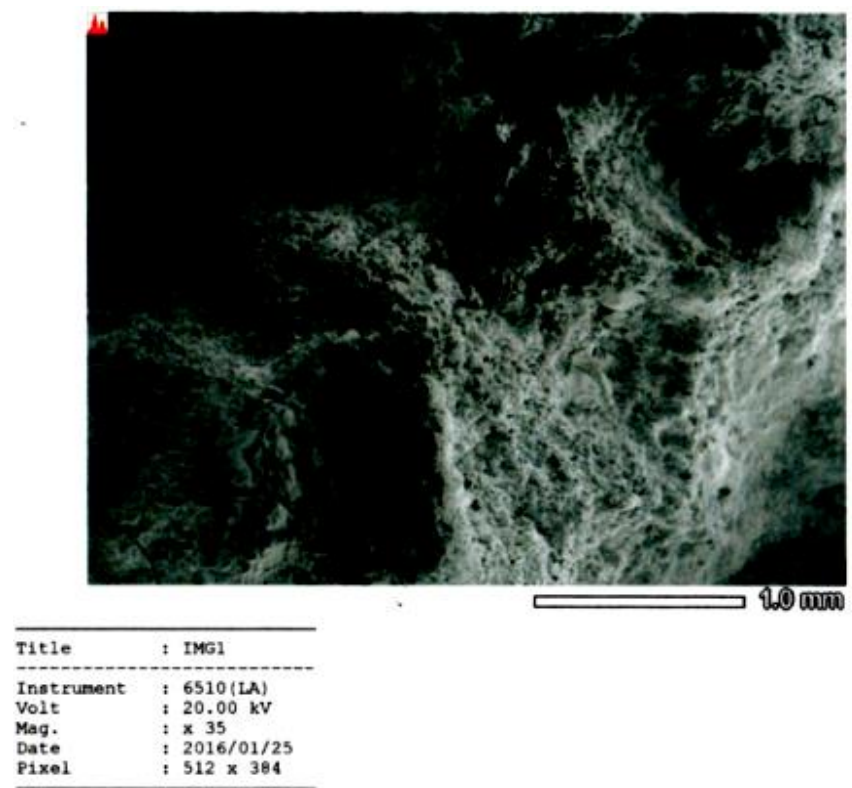

Gambar 26.

Hasil SEM dari Permukaan Impeller Pompa pada Posisi 2
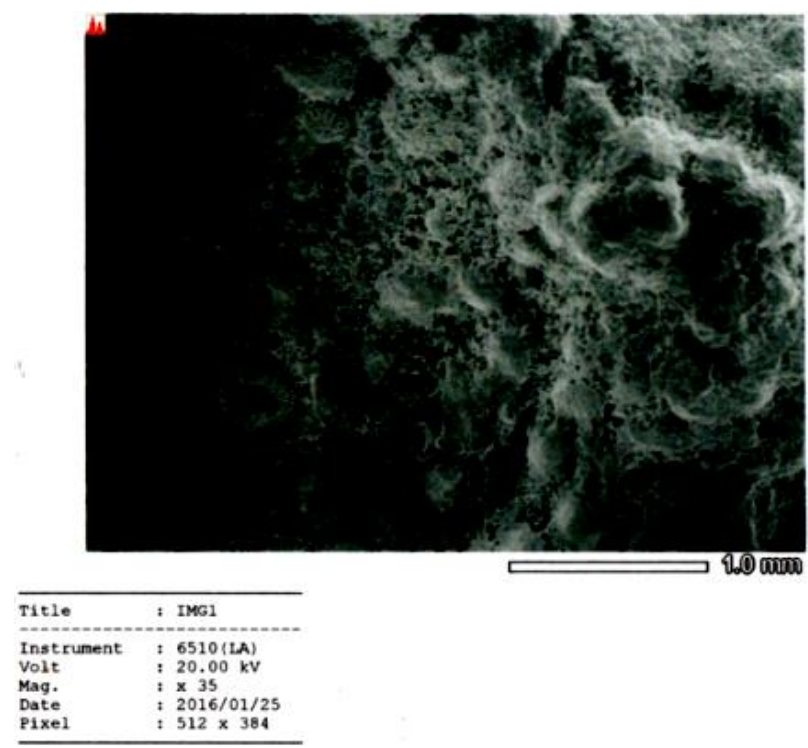

Gambar 27.

Hasil SEM dari Permukaan Impeller Pompa pada Posisi 3

Tabel 3.

Analisis EDS pada Produk Korosi di Permukaan Impeller

\begin{tabular}{ccc}
\hline No. & Nama Unsur & $\begin{array}{c}\text { Kandungan Unsur } \\
(\%)^{*}\end{array}$ \\
\hline 1 & $\mathrm{C}$ & 12,12 \\
2 & $\mathrm{O}$ & 29,53 \\
3 & $\mathrm{Si}$ & $0,55^{\star *}$ \\
4 & $\mathrm{~S}$ & 1,07 \\
5 & $\mathrm{Cl}$ & $0,33^{* * *}$ \\
6 & $\mathrm{Ca}$ & $1,29^{\star *}$ \\
7 & $\mathrm{Fe}$ & $1,17^{\star *}$ \\
8 & $\mathrm{Cu}$ & 52,56 \\
9 & $\mathrm{Zn}$ & 2,61 \\
\hline
\end{tabular}

*Semi kuantitatif, nilai rata-rata dari 3 posisi pengukuran

${ }^{* *}$ Hasil pengukuran hanya terlihat pada 2 posisi dari 3 posisi pengukuran

***Hasil pengukuran hanya terlihat pada 1 posisi dari 3 posisi pengukuran

\section{PEMBAHASAN}

Hasil dari beberapa pemeriksaan, pengujian, dan analisis menunjukkan bahwa impeller pompa secara kimiawi terkorosi oleh kandungan ion klorin dan ion sulfur yang 
jelas terlihat dari analisis EDS. Dalam beberapa literatur menunjukkan bahwa sejumlah kandungan ion klorin akan merusak silicon brass $8-9,17-18)$. Analisis komposisi kimia menunjukkan bahwa impeller terbuat dari silicon brass (ASTM B198-13A Grade C87400). Logam silicon brass kurang tahan terhadap lingkungan yang banyak mengandung kandungan klorin dibandingkan silicon red brass. Sebagai tambahan, paduan tembaga dengan kandungan unsur Zinc melebihi $15 \%$ lebih rentan terhadap dezincification seperti yang terjadi pada kerusakan impeller pompa.

\section{SIMPULAN}

Dari hasil observasi, pengamatan, dan analisis laboratorium serta pembahasan dapat disimpulkan bahwa penyebab kerusakan impeller pompa utamanya diperburuk oleh dezincification ${ }^{19-21)}$ yang disebabkan karena kehadiran unsur korosif seperti ion $\mathrm{Cl}^{-}$dan $\mathrm{S}^{2-}$ dalam air laut. Material yang digunakan untuk impeller yaitu ASTM B198-13A merupakan jenis silicon brass yang merupakan material yang tidak tahan terhadap serangan korosi dibandingkan leaded red brass.

\section{SARAN}

Saran yang perlu dilakukan untuk mencegah terjadi kerusakan yang sama di masa mendatang yaitu mengganti material impeller dari jenis silicon brass menjadi leaded red brass yang lebih tahan terhadap serangan dezincification.

\section{UCAPAN TERIMA KASIH}

Penulis mengucapkan terima kasih kepada Ir. Sudarmadi, M.Eng., MSc. selaku Kepala B2TKS BPPT, Dr.Ing.H.Agus Suhartono selaku Kepala Bidang Kajian Material B2TKS, dan Sutarjo, ST, MM selaku Kepala Sub Bidang Analisis Kerusakan dan Umur Sisa untuk koordinasi dan pemberian ijin dalam menggunakan alat uji laboratorium.

\section{DAFTAR PUSTAKA}

1. Rules and Regulations for the Construction and Classification of Steel Ships: Part 1, Indian Register of Shippings, 2017.
2. Standard Specification for Copper Alloy Sand Castings for General Applications, American Standard of Testing Material, ASTM B584-14, 2014.

3. William D. Callister, Fundamentals of Materials Science and Engineering 5th edition, John Willey \& Sons Inc., 2001.

4. Josifovic, Aleksandar, Jennifer J. Roberts, dkk, "Reducing the environmental impact of hydraulic fracturing through design optimisation of positive displacement pumps", Energy, 115,2016 , hal. 1216-1233

5. Lee, D.I., dan H.C.Lim, "ErrosionCorrosion Damages of Water Pump Impeller", International Journal of Automotive Technology, 10 (5), 2009, hal.629-634

6. Sharma, Pankaj, "Premature Failure of Ductile Iron Pump Impeller in Cooling Tower System", Journal Failure Analysis and Prevention, 14, 2006, hal. 303-306

7. Lee, Dong-Bok, dan Jae-Jin Moon, "The effect of small additions of $\mathrm{Zr}, \mathrm{Cr}, \mathrm{Mg}, \mathrm{Al}$, and $\mathrm{Si}$ on the oxidation of $6: 4$ brass", Metal and Materials International, 8 (2), 2002, hal. 327-332

8. M.G.Fontana, Corrosion Engineering, hal. 86-88, McGraw- Hill Book Company, New York ,1986.

9. Denny A. Jones, Principle and Prevention of Corrosion, Macmillan Publishing Company, NewYork ,1992.

10. Rules for The Classification and Construction, Part 1: Seagoing Ships, Volume I, Biro Klasifikasi Indonesia, 2014.

11. Drach, Andrew, dkk, "Field studies of corrosion behaviour of copper alloys in natural seawater", Corrosion Science, 76 ,2013, hal.453-464

12. Nady, H., M.M. El-Rabiei, dan M.Sany, "Corrosion Behaviour and electrochemical properties of carbon steel, commercial pure titanium, copper, and copper-aluminum-nickel alloy in 3,5\% sodium chloride containing sulfide ions", Egyptian Journal of Petroleum, 2016.

13. Wang Y.H., dkk, "Microstructure and mechanical properties of columnargrained copper produced by Ohno continous casting techniques", Material Science and Engineering A, 639, 2015, hal. 122-130Du, X.S, dkk, "Inhibitive and mechanism of phosphates on the stress corrosion cracking of brass in ammonia solutions", Corrosion Science, 60, 2012, hal. 69-75 
14. Bravenec, Edward V. dan J. Edgar Zapata, "Metallurgical Failure Analysis of A Domestic Water Pump Impeller", Engineering Failure Analysis, Vol. 1, No.1, 1994, hal. 29-34

15. Bauccio, Michael L., ASM Metals Reference Handbook 3rd Edition, hal.458-459, ASM International, Metal Park, Ohio, 1999.

16. Failure Analysis and Prevention, Metal Handbook, Vol. 11, 9th edition, hal. 187221, and 632, American Society for Metals, Metal Park, Ohio, 1986.

17. Corrosion, Metals Handbook, Vol. 13 9th edition, hal. 131 dan 614, American Society for Metals, Metal Park, Ohio, 1986.
18. Kumar, Satendra, dkk,"Effect of lead content on the dezinfication behaviour of leaded brass in neutral and acidified $3,5 \% \mathrm{NaCl}$ solution", Materials and Chemistry and Physics, 105 (1), 2007, hal. 131-141

19. Troiani, H.E., dan A.Baruj, "In situ optical microscopy study of a phase transformation induced by the dezinfication of beta Cu-Zn", Material Science and Engineering : A, 454-455 ,2007, hal. 441-445

20. Campanella, L., dkk, "The effect of tin on dezinfication of archaelogical copper alloy", Corrosion Science, 51 (9) , 2009, hal.2183-2191 